\title{
PROMOSI KESEHATAN TENTANG PENCEGAHAN KANKER SERVIKS MELALUI PEMANFAATAN MEDIA ONLINE HEALTH PROMOTION OF CERVICAL CANCER PREVENTION USING ONLINE MEDIA
}

\author{
Elsa Fitri Ana ${ }^{1,2^{*}}$, Mienna Yuniarti ${ }^{2,3}$, Isnul Jumrotul Jannah ${ }^{2}$, Miratul \\ Hasanah $^{2}$, Sulastri ${ }^{2}$, Nila Qurniasih ${ }^{1}$, Nopi Anggista Putri ${ }^{1}$ \\ ${ }^{1}$ Program Sarjana Kebidanan dan Profesi Bidan, Fakultas Kesehatan, Universitas \\ Aisyah Pringsewu, Indonesia \\ ${ }^{2}$ Women's Pedia, Indonesia
}

Email Korespondensi: Uapelsafitriana@gmail.com

Disubmit: 28 Oktober $2021 \quad$ Diterima: 23 Desember $2021 \quad$ Diterbitkan: 02 Januari 2022 DOI: https://doi.org/10.33024/jkpm.v1i1.5390

\begin{abstract}
ABSTRAK
Kanker serviks adalah penyebab kematian tertinggi keempat pada wanita di dunia. Tingginya angka kesakitan dan kematian wanita akibat kanker serviks di Indonesia, juga menunjukkan rendahnya angka cakupan pemeriksaan papsmear dan imunisasi HPV di Indonesia. Oleh karena itu dibutuhkan metode promosi kesehatan untuk mendorong wanita untuk aktif dalam melakukan pencegahan kanker serviks. Kegiatan ini merupakan salah satu bentuk pengabdian masyarakat yang dilakukan dengan cara penyuluhan melalui metode ceramah dan diskusi dengan aplikasi zoom dan whatsapp. Peserta yang mendaftar dalam kegiatan ini sejunlah 41 orang dengan rentang usia 20-35 tahun. Peserta berasal dari berbagai daerah antara lain, Jakarta, Lampung, Surabaya, Malang, Palu dan Banjarmasin. Materi yang telah disampaikan menyatakan bahwa pencegahan kanker serviks dapat dilakukan sedini mungkin. Dibandingkan dengan metode penyuluhan yang dilakukan secara langsung, pemanfaatan media sosial terbukti efektif dalam mencapai jangkauan keluasan sasaran.
\end{abstract}

Kata kunci: kanker serviks, pencegahan, deteksi dini, HPV

\begin{abstract}
Cervical cancer is the fourth main cause of death in women in the world and the main cause of death for women in developing countries. The high morbidity and mortality rates for women due to cervical cancer in Indonesia also shows the low coverage rates for Pap smear test and HPV immunization in Indonesia. Therefore a health promotion is needed to encourage women to be active in preventing cervical cancer. This event is a form of counseling through lectures and discussions with zoom and WhatsApp applications. The number of participants who participated in this activity was 41 peoples in age from 20-35 years from various provinces including Jakarta, Lampung, Surabaya, Malang and Banjarmasin. The subject that has been presented states that cervical cancer prevention can be done as early as possible. Compared to conventional health promotion methods, the use of social media has proven to be effective in reaching a broad target.
\end{abstract}

Keywords: cervical cancer, prevention, early detection, HPV 


\section{PENDAHULUAN}

Kanker serviks adalah penyebab kematian tertinggi keempat pada wanita di dunia setelah kanker payudara (Arbyn et al, 2020). Sejumlah 570.000 kasus dan 311.000 kasus kematian akibat kanker serviks diperkirakan muncul pada tahun 2018 di dunia (Arbyn et al, 2020). Kanker serviks merupakan salah satu masalah utama kesehatan reproduksi pada perempuan di Indonesia. Menurut data dari Kementerian Kesehatan Republik Indonesia (Kemenkes RI) pada tahun 2013, kejadian kanker serviks di Indonesia sebesar 0,8\%. Provinsi yang memiliki estimasi jumlah penderita kanker serviks terbesar adalah Provinsi Jawa Timur dengan estimasi 21.313 kasus.(Kemenkes RI, 2015).

Penyebab utama kanker serviks adalah HPV (human papillomavirus) (Howlader et al, 2012). HPV juga menyebabkan kanker vulva, kanker vagina, kanker penis, dan kanker anus (Howlader et al, 2012). Selain itu kanker orofaring yang disebabkan oleh HPV juga meningkat dengan estimasi 30\%-50\% (Kreimer et al, 2005). HPV dibagi menjadi 2 golongan yaitu HPV resiko rendah dan HPV resiko tinggi. Infeksi HPV resiko rendah mencakup HPV subtype $6,11,8$ dan menyebabkan kutil pada manusia. Sedangkan HPV resiko tinggi menyebabkan kanker pada manusia yaitu HPV tipe 16 dan 18 (Munoz et al, 2003).

HPV dapat ditularkan dengan melalui kontak langsung yaitu dengan hubungan seksual dan kontak kulit (skin to skin) (doorbar et al, 2012). Khusus untuk HPV resiko tinggi hanya dapat ditularkan dengan aktivitas seksual (Sugiyama et al, 2007). Kontak kulit dapat menularkan HPV resiko rendah (Sugiyama et al, 2007).

Strategi global Organisasi Kesehatan Dunia (WHO) untuk pemberantasan kanker serviks pada tahun 2030 menguraikan tiga pilar utama pemberantasan kanker serviks, yaitu pencegahan, skrining, dan pengobatan. WHO merekomendasikan untuk memenuhi target global eliminasi saat ini, setiap negara harus mencapai cakupan $90 \%$ dari HPV. vaksinasi anak perempuan (pada usia 15 tahun); 70\% cakupan skrining dan $90 \%$ pengobatan lesi prakanker; dan pengelolaan 90\% kasus kanker invasif (World Health Organization, 2020). Pencegahan dilakukan dengan imunisasi HPV (Hausen, 2002). Imunisasi ini diberikan pada wanita yang belum aktif secara seksual terutama pada remaja. Saat ini ada 2 macam imunisasi HPV yang beredar yaitu Cervarix dan Gardasil (Hathaway, 2012). Kedua imunisasi ini memiliki efektifitas perlindungan sampai dengan 90\% terhadap HPV tipe 16 dan 18 (Olsson et al, 2007). Gardasil dapat diberikan juga kepada remaja pria. Kanker serviks dapat diantisipasi dengan melakukan deteksi dini. Beberapa deteksi dini yang bisa digunakan untuk mengetahui keberadaan kanker serviks adalah Pap Smear, Pap net, servikografi, tes inspeksi visual asam asetat (IVA), tes high-risk type (HPV), kolposkopi, dan sitologi berbasis cairan. (Soebrachman dan Awas, 2011).

\section{MASALAH}

Pemasalahan yang kami angkat karena tingginya angka kesakitan dan kematian wanita akibat kanker serviks di Indonesia, juga menunjukkan rendahnya angka cakupan pemeriksaan papsmear dan imunisasi HPV di Indonesia. Oleh karena itu dibutuhkan metode promosi kesehatan untuk mendorong wanita untuk aktif dalam melakukan pencegahan kanker serviks. Kegiatan ini bertujuan untuk memberikan informasi mengenai kanker serviks dan pencegahannya, sehingga wanita dapat termotivasi untuk melakukan deteksi dini. Kegiatan dilakukan secara online sehingga tidak menampilkan peta lokasi kegiatan. 


\section{METODE}

Kegiatan ini merupakan salah satu bentuk pengabdian masyarakat yang dilakukan dengan cara penyuluhan melalui metode ceramah dan diskusi. Ceramah dilakukan dengan menggunakan aplikasi zoom selama 20 menit. Koordinasi dan tindak lanjut diskusi dilakukan melalui aplikasi whatsapp. Hasil video promosi akan diunggah ke aplikasi youtube. Sasaran kegiatan ini adalah wanita usia reproduktif dan menopause antara 15-65 tahun.

Metode dan tahap pelaksanaan, meliputi:

1) Menyusun topik promosi kesehatan

2) Menghubungi dan meminta kesediaan narasumber

3) Publikasi kegiatan melalui media sosial Instagram, facebook, dan status whasapp kepada masyarakat yang dilakukan 3 minggu sampai $\mathrm{H}-1$ sebelum kegiatan

4) Registrasi peserta kegiatan

5) Membuat grup melalui aplikasi whatsapp untuk berkoordinasi dan diskusi dengan peserta

6) Membagikan undangan link aplikasi zoom satu hari sebelum kegiatan

7) Membuat sertifikat untuk narasumber dan peserta

8) Melakukan gladi bersih satu hari sebelum kegiatan berlangsung

\section{HASIL DAN PEMBAHASAN}

Topik dari kegiatan ini adalah promosi kesehatan kanker serviks dengan judul "Yuk Kenali dan Cegah Kanker Serviks Sedini Mungkin". Pemilihan topik diambil berdasarkan permasalahan utama dalam kesehatan reproduksi wanita. Metode yang dipilih adalah ceramah melalui aplikasi dan sosial media dengan tujuan untuk meminimalisir kontak langsung dan kerumunan dalam rangka pencegahan penularan penyakit Covid-19.

Pelaksana kegiatan ini adalah tim dari Women's Pedia dan dosen Universitas Aisyah Pringsewu. Women;s pedia merupakan wadah yang dibuat oleh beberapa bidan dari alumni S1 Pendidikan Bidan Universitas Airlangga dengan fokus promosi kesehatan ibu dan anak.

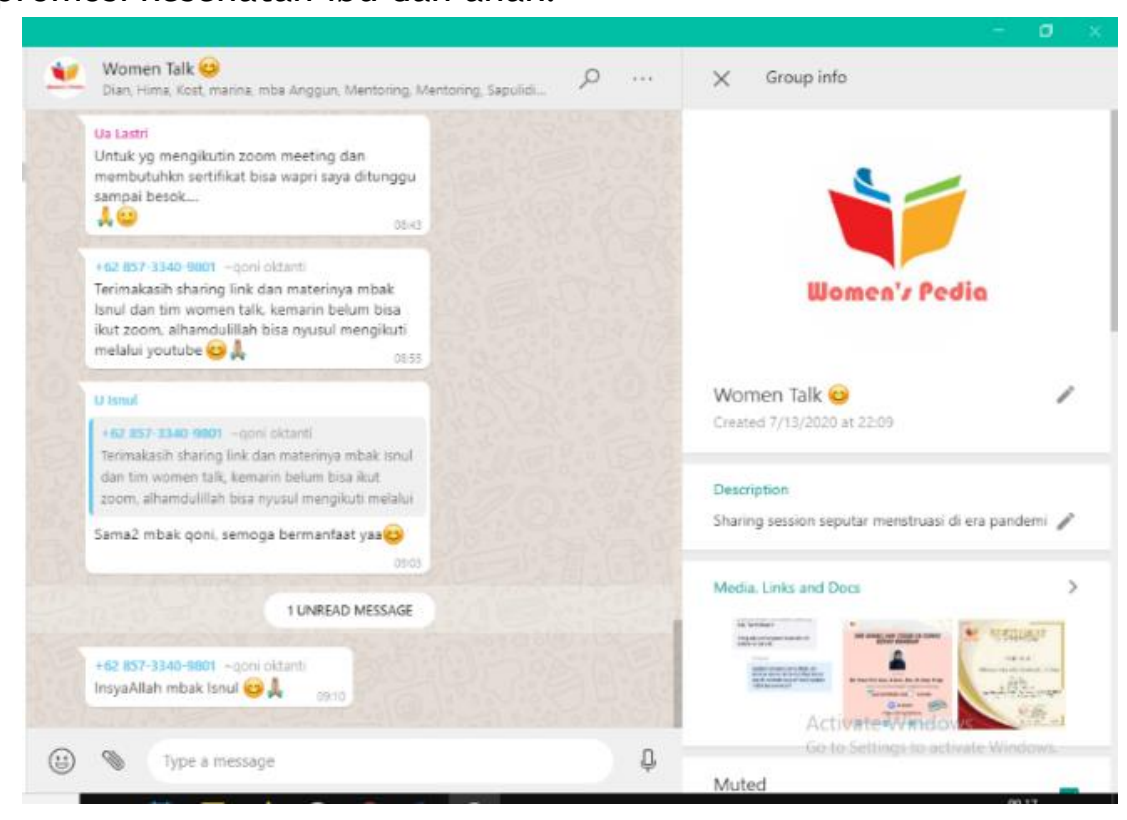

Gambar 1. Grup whatsapp untuk korrdinasi dan tindak lanjut diskusi dengan peserta. 


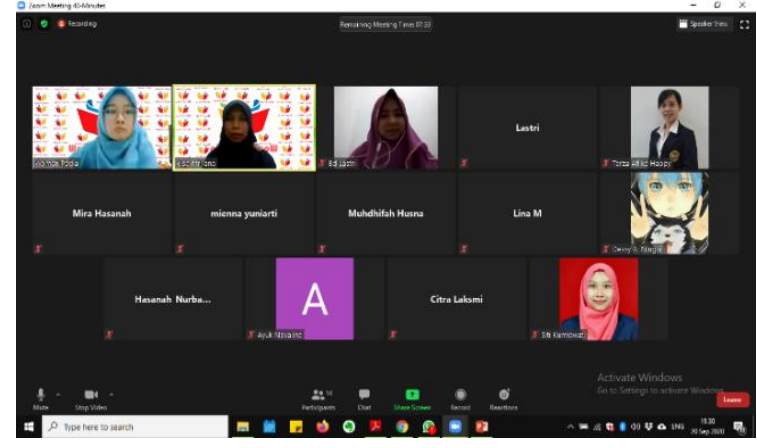

Gambar 2. Zoommeeting pelaksaanan promosi kesehatan

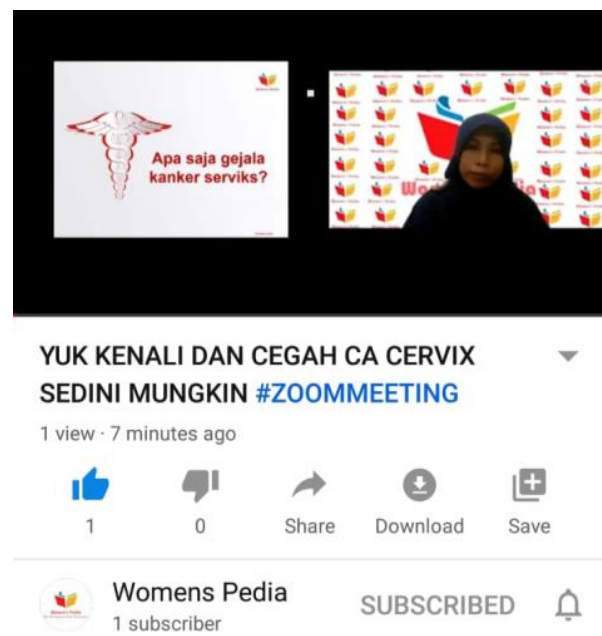

Gambar 3. Video promosi kesehatan yang diunggah ke aplikasi youtube

Peserta yang mendaftar dalam kegiatan ini sejunlah 41 orang dengan rentang usia 20-35 tahun. Pada wanita usia 20-39 tahun, kanker serviks terus menjadi penyebab kematian kedua dan menyebabkan 10 kematian dini per minggu (Hausen, 2002). Kelompok usia ini sudah masuk dalam kategori seksual aktif, sehingga kelompok ini membutuhkan informasi yang benar dalam pencegahan dan deteksi dini kanker serviks.

Peserta berasal dari berbagai daerah antara lain, Jakarta, Lampung, Surabaya, Malang, Palu dan Banjarmasin. Dibandingkan dengan metode penyuluhan yang dilakukan secara langsung, pemanfaatan media sosial terbukti efektif dalam mencapai jangkauan keluasan sasaran. Media sosial semakin banyak digunakan untuk publik promosi kesehatan dan kesehatan: 60\% departemen negara bagian di Amerika Serikat menggunakan satu atau lebih banyak aplikasi media sosial (Neiger et al, 2012). Media sosial sudah menjadi bagian dari kehidupan manusia saat ini. tenaga kesehatan diharapkan mampu memanfaatkan sarana dan prasarana yang dapat menyesuikan dengan perubahan zaman. Selain itu kerjasama yang dibangun dalam pelaksanaan kegiatan ini juga dapat menjangkau kelompok lain di luar daerah, sehingga dapat terjalin hubungan inter-institusi.

Kegiatan ini dilaksanakan pada Minggu, 20 September 2020 pkl 19.10 19.50 WIB. Pembukaan dilakukan selama 10 menit, pemberian materi dilakukan selama 20 menit dan diskusi selama 10 menit. Pertanyaan yang belum terjawab 
saat kegiatan dilanjutkan di dalam grup whatsapp sampai pukul 20.30 WIB. Peserta sangat antusias dalam mengikuti jalannya kegiatan dan diskusi topik yang disampaikan.

Melalui penyuluhan ini diharapkan mampu memberikan informasi kepada wanita untuk mencegah dan deteksi dini kanker serviks. Sampai saat ini kanker serviks merupakan salah satu penyebab kematian tertinggi pada wanita setelah kanker payudara. Saat ini pencegahan dan deteksi dini merupakan upaya yang paling efektif dalam menurunkan angka kesakitan dan kematian akibat kanker serviks. Program yang mendukung dalam memberikan informasi dan meningkatkan kesadaran wanita untuk mau melakukan pencegahan dan deteksi dini harus ditingkatkan.

\section{KESIMPULAN}

Kesimpulan dari materi yang telah disampaikan bahwa pencegahan kanker serviks dapat dilakukan sedini mungkin dengan beberapa cara yang disesuaikan dengan kelompok usia, antara lain imunisasi HPV, skrining dengan papsmear dan IVA, seks sehat, dan gaya hidup sehat.

Imunisasi diberikan pada kelompok usia reproduktif yang belum aktif secara seksual, terutama pada remaja. Skrining wajib dilakukan oleh wanita yang sudah menikah atau sudah aktif secara seksual. Papsmear dilakukan minimal 2 tahun sekali. Seks sehat meliputi setia pada satu pasangan, menggunakan kondom untuk mencegah infeksi menular seksual, dan sunat pada pria. Gaya hidup sehat dapat dilakukan dengan tidak merokok baik aktif atau pasif, mengkonsumsi makanan dan minuman sehat untuk menjaga sistem imun, serta menjaga kebersihan daerah kewanitaan dengan benar.

Keterbatasan kegiatan ini adalah beberapa kelompok usia yang tidak mendaftar sebagai peserta yaitu kelompok usia remaja (12-18 tahun) dan kelompok usia menopause (>45 tahun). Perlu diberikan metode promosi kesehatan lain yang dapat mencapai sasaran usia yang diharapkan. Bekerja sama dengan institusi pendidikan dan kesehatan atau menggunakan media sosial yang sering diakses oleh kelompok usia tersebut dapat dilakukan untuk promosi kesehatan selanjutnya.

\section{DAFTAR PUSTAKA}

Arbyn M, Weiderpass E, Bruni L, et al. (2020). Estimates of incidence and mortality of cervical cancer in 2018: a worldwide analysis. Lancet Global Health, 8(2).

Doorbar J, Quint W, Banks L, Bravo IG, Stoler M, Broker TR, Stanley MA. (2020). The biology and life-cycle of human papillomaviruses. Vaccine. 30(Suppl 5):F55-70.

Hausen, H. Z. (2002). Papillomaviruses and cancer: from basic studies to clinical application. Nat Rev Canc 2(5), 342e350.

Howlader N, Noone AM, Krapcho M, SEER Cancer Statistics Review, 1975-2008. 2012; Available at: http://seer.cancer.gov/csr/1975_2008/. Accessed January 26, 2012

Kementerian Kesehatan Republik Indonesia. Profil Kesehatan Indonesia Tahun 2015. Jakarta: Kementerian Kesehatan RI; 2015.

Kepmenkes RI. Kepmenkes RI Nomor 796/MENKES/SK/VII/2010 tentang Pedoman Kanker Payudara dan Kanker Leher Rahim. Jakarta: Kemenkes RI; 2010.

Kreimer AR, Clifford GM, Boyle P, et al. (2005). Human papillomavirus types in 
head and neck squamous cell carcinomas worldwide: a systematic review. Cancer Epidemiol Biomarkers Prev. 14: 467-475.

Muñoz, N., Bosch, F. X., Sanjosé, S. D., et al. (2003). Epidemiologic classification of human papillomavirus types associated with cervical cancer. $N$ Engl $J$ Med, 348(6), 518e527.

Neiger BL, Thackeray R, Van Wagenen SA, Hanson CL, West JH, Barnes MD, et al. (2013). Use of social media in health promotion: purposes, key performance indicators, and evaluation metrics. Health Promot Pract. 13(2):159-64.

Olsson SE, Villa LL, Costa RL, et al. (2007). Induction of immune memory following administration of a prophylactic quadrivalent human papillomavirus (HPV) types 6/11/16/18 L1 virus-like particle (VLP) vaccine. Vaccine. 25:4931-4939.

Soebrachman A. Awas. 7 Kanker Paling Mematikan. Yogyakarta: Syura Media Utama; 2011.

World Health Organization. (2020). In Draft: Global Strategy towards the Elimination of Cervical Cancer as a Public Health Problem. https://www.who.int/docs/default-source/documents/cervical-cancerelimination-draft-strategy.pdf Accessed 2020. 